\title{
PENGEMBANGAN KREATIVITAS IMAJINATIF ABAD KE-21 DALAM PEMBELAJARAN SEJARAH
}

\author{
Nana Supriatna \\ Departemen Pendidikan Sejarah, FPIPS, UPI \\ nanasup@upi.edu
}

Abstract: $\quad$ This article was developed from the observation of the learning process carried out by the History teacher and students of the Field Experience Program (PPL) participants of the History Education Department, UPI, in one of the high schools in Bandung. History Learning aims to develop the imaginative abilities of students in the past about the past. For historians, imagination is the power to present the past to the time where the reader is. Historical Learning contains the delivery of a number of historical facts that will not produce imaginative abilities, but questions using the technique of "if history" or the technique of wishing to make students can imagine. Imagination can develop well if the teacher can facilitate students with imaginative historical material through a learning process that stimulates them to develop their imagination. Through imagination, students can be anyone or do anything (certainly good) in their memories, thoughts, images or hopes. Imagination is a thinking power that describes creativity. Historical imagination contains an element of empathy because the students above imagine to become a historical figure while empathizing with it.

Abstrak: $\quad$ Artikel ini dikembangkan dari hasil observasi terhadap proses pembelajaran yang dilakukan oleh guru Sejarah dan mahasiswa peserta Program Pengalaman Lapangan (PPL) Departemen Pendidikan Sejarah, UPI, di salah satu SMA di Bandung. Pembelajaran Sejarah bertujuan mengembangkan kemampuan imajinatif peserta didik tentang masa lalu. Bagi sejarawan, imajinasi merupakan kekuatan untuk menghadirkan masa lalu ke masa dimana pembaca berada. Pembelajaran Sejarah berisi penyampaian sejumlah fakta sejarah tidak akan menghasilkan kemampuan imajinatif, namun pertanyaan dengan menggunakan teknik "if history" atau teknik berandai-andai membuat siswa dapat berimajinasi. Imajinasi bisa berkembang dengan baik kalau guru bisa memfasilitasi peserta didik dengan materi sejarah yang imajinatif melalui proses pembelajaran yang merangsang mereka mengembangkan imajinasinya. Melalui imajinasi, peserta didik bisa menjadi siapapun atau berbuat apapun (tentu yang baik) dalam ingatan, pikiran, bayangan atau harapannya. Imajinasi merupakan kekuatan berpikir yang yang menggambarkan kreatifitas. Imajinasi kesejarahan mengandung unsur empati karena peserta didik di atas berimajinasi untuk menjadi seorang tokoh sejarah sekaligus berempati terhadapnya

Kata Kunci: berpikir kreatif-imajinatif, keterampilan abad ke-21, pembelajaran sejarah,

\section{PENDAHULUAN}

"Bangsa Indonesia belum merdeka sejak tahun 1945”. Itulah jawaban seorang peserta didik di salah satu Sekolah Menengah Atas (SMA) di Bandung ketika ditanya gurunya dengan kalimat tanya "Bagaimana cara bangsa Indonesia mengisi kemerdekaan setelah memproklamasikan kemerdekaannya pada tanggal 17 Agustus 1945? Jawaban itu muncul ketika guru melontarkan pertanyaan kepada seluruh kelas dan salah seorang siswa mengangkat tangan dan langsung menjawabnya.

Kegiatan tanya jawab itu berlangsung saat seorang guru pamong mengajar sesuai Kurikulum Tahun 2013. Melalui dialog antara dosen, mahasiswa dan guru pamong disepakati kegiatan pembelajaran lebih fokus pada pencapaian kompetensi inti kedua (KI-2) disamping pencapaian Kompetensi Dasar (KD). Salah satu unsur KI-2 adalah kreatifitas yang dikembangkan lebih lanjut menjadi kreatifitas-imajinatif serta dihubungkan dengan keterampilan yang banyak digarap oleh kalangan pendidik guna menyiapkan peserta didik berperan aktif di abad ke-21 ini. Creativity and Innovation yang dikembangkn oleh Trilling and Fadel (2009), Piirto (2011) dan Griffin (2012), digunakan sebagai rujukan. Kurikulum Tahun 2013 dijadikan sebagai guideline terkait dengan $\mathrm{KI}$ dan $\mathrm{KD}$ dan diperkaya dengan curriculum as an experiences dan dikembangkan dalam pembelajaran kontekstual. Peserta didik ditempatkan sebagai pelaku sejarah pada zamannya (Supriatna, 2007).

Penulis tidak merasa kaget ketika guru sejarah bereaksi negatif terhadap jawaban peserta didik di atas. Mungkin juga dalam pikirannya terbersit bahwa ini adalah jawaban siswa yang bodoh. Siswa SMA dianggap belum juga fasih "di luar kepala" menyebut secara spontan bahwa Proklamasi Kemerdekaan Republik Indonesia terjadi pada tanggal 17 Agustus 1945. Bukanlah dalam pelajaran IPS di sekolah dasar juga sudah ada materi sejarah bahwa Prokamasi Kemerdekaan RI secara faktual terjadi tanggal tersebut. Seharusnya peserta didik bisa menjawab secara spontan dengan benar.

Penulis juga tidak kaget ketika guru mengatakan bahwa jawaban peserta didik adalah seratus persen salah. Kenyataannya, dalam buku teks yang mengacu pada Kurikulum Tahun 2013 atau kurikulum-kurikulum tahun sebelumnya serta dalam buku-buku Sejarah yang direkomendasikan pemerintah peristiwa proklamasi kemerdekaan dicatat terjadi pada tanggal 17 Agustus 1945. Artinya, sejak peristiwa terebut bangsa Indonesia sudah merdeka dari penjajahan. Jawaban bahwa bangsa Indonesia belum merdeka sejak tahun 1945

HISTORIA: Jurnal Pendidik dan Peneliti Sejarah, p-issn:2620-4789 | e-issn:2615-7993 
adalah jawaban yang keliru. Bila fakta sejarah itu masuk ke dalam soal-soal pilihan ganda - sebagaimana sebagian besar guru-guru Sejarah melakukan penilaian - maka siswa yang menjawab di luar tanggal itu atau pilihan bahwa bangsa Indonesia belum merdeka sajak tahun 1945 akan mendapat skor nol.

Nampaknya guru Sejarah sedang melaksanakan "pesanan" Kurikulum Tahun 2013. Dalam Kurikulum yang berlaku tersebut belajar dilakukan dengan cara $5 \mathrm{M}$, yaitu mengamati, menanya, mencoba, menalar (mengolah informasi) dan mengomunikasikan. Belajar harus dilakukan secara aktif dengan melibatkan peserta didik. Pembelajaran tidak lagi berpusat pada guru melainkan siswa. Banyak guru sejarah menerjemahkan belajar aktif itu dengan kegiatan tanya jawab atau diskusi kelas. Guru tidak memaknai belajar aktif itu menggunakan secara aktif kemampuan kognitifnya dengan berpikir kritis, kreatif, reflektif atau kreatif-imajinatif terhadap materi Sejarah yang dipelajarinya. Guru juga tidak berusaha memfasilitasi peserta didik bahwa belajar aktif itu dengan melakukan kegiatan pembelajaran berbasis model based learning, problem based learning dan inquiry sebagaimana ditawarkan dalam kurikulum terebut.

Secara konvensional, pembelajaran sejarah bertujuan mengembangkan kemampuan imajinatif peseta didik tentang masa lalu. Sudah lama di Amerika Serikat, misalnya, pembelajaran sejarah diarahkan untuk membangun kemampuan imajinasi peserta didik. Imajinasi merupakan salah satu kemampuan dasar bagi sejarawan dan pembelajar Sejarah memaknai peristiwa sejarah. Hart, dalam jurnal The American Historical Review, Vol 15 No 2 (January 2010) pp 227-251) pada artikelnya berjudul Imagination in History menyatakan bahwa abad ke-18 merupakan masa puncak bagi sejarawan Eropa mengembangkan karya imajinatif dalam historiography-nya. Karya mereka tidak hanya berbasis fakta melainkan didasarkan kemampuan berimajinasi penulisnya. Bagi sejarawan, imajinasi merupakan kekuatan untuk menghadirkan masa lalu ke masa dimana pembaca berada. Tidak terlalu penting, apakah karyanya ilmiah atau hanya sekedar fiksi. Fiksi yang berisi sejumlah narasi menggambarkan kemampan penulisnya dalam berimajinasi. Dalam pembelajaran sejarah di Indonesia, guru-guru sejarah tradisional lebih sering menggunakan kemampuannya bercerita dengan tujuan agar peserta didik masuk ke ruang atau waktu di mana materi sejarah diceritakan. Kemampuan guru bercerita itu bisa mendorong peserta didik mengembangkan kemampuan imajinatifnya.

Berdasarkan pengamatan yang penulis lakukan di atas, pembelajaran sejarah lebih banyak berisi penyampaian sejumlah fakta sejarah. Penyampaian seperti itu tentu tidak akan menghasilkan kemampuan imajinatif, sebagai salah satu ciri dari kemampuan berpikir kreatif. Guru memang berusaha membuat peserta didik aktif bertanya. Akan tetapi, kegiatan tanya jawab lebih fokus pada hal-hal yang sifatnya bisa dihapal dan diingat. Posisi kursi di ruang kelas digeser-geser untuk memfasilitasi peserta didik berdiskusi sesuai kelompok. Dalam praktiknya yang dimaksud diskusi adalah melakukan kerja kelompok untuk menjawab sejumlah pertanyaan yang sifatnya faktual. Pertanyaan dengan menggunakan kata tanya apa, siapa, kapan dan di mana merupakan pertanyaan yang harus dikerjakan atau dijawab secara berkelompok. Jarang terdengar kata tanya untuk mengelaborasi kemampuan berpikir tingkat tingi dengan kata tanya mengapa dan bagaimana. Pertanyaan di atas dijawab secara kolektif oleh peserta didik dengan membaca buku teks sebagaimana kata mengamati yang juga diterjemahkan dengan menyimak isi buku dalam cara belajar saintifik. Melalui cara belajar seperti ini peserta didik nampak dikondisikan aktif dalam melakukan akifitas berpikir tingkat rendah, yaitu recall meminjam istilah yang dikembangkan oleh Bloom dalam taksonominya. Sulit dicapai kompetensi inti yang sarat dengan sejumlah nilainilai karakter atau kemampuan berpikir tingkat tinggi/higher order thinking skills (HOTS), seperti berpikir kreatif, berpikir reflektif atau melakukan kegiatan yang bersifat inovatif.

Nampaknya guru bekerja sebagai bagian dari instrument kurikulum secara prosedural. Kurikulum disusun sedemikian rupa dan diisi dengan sejumlah tujuan yang harus dicapai melalui proses pembelajaran. Untuk mencapai tujuan itu tidak dilakukan dengan memilih materi pelajaran sebab hal itu sudah tersedia dalam buku teks yang dibuat oleh pemerintah. Tentu saja isinya dengan menggunakan hasil interpretasi sesuai dengan kepentingan politik. Di manapun di dunia, pemerintah punya kepentingan politik atas kurikulum (Hasan, 2004). Untuk mengukur ketercapaian tujuan itu dilakukan penilaan, baik penilaian hasil maupun proses. Dalam Kurikulum Tahun 2013, penilaian kontekstual dan kinerja juga ditawarkan. Namun demikian, dalam praktiknya, berdasarkan pengalaman di lapangan, penilaian lebih banyak dilakukan melalui tes. Untuk mencapai hasil yang baik, peserta didik dilatih menjawab soal-soal agar bisa mendapat nilai baik pada ulangan yang secara rutin dijadwalkan di kelas. Tidak terlalu penting bagi guru, apakah peserta didik memiliki kepampuan berpikir tingkat tinggi, berpikir kreatif dan innovatif atau memiliki karakter sebagaimana dipesankan dalam KI 2. Yang penting adalah hasil belajar: bisa menjawab soal-soal faktual yang bisa dihapal dan diingat.

Tidak penting juga bagi guru untuk melakukan elaborasi terhadap jawaban peserta didik yang menjawab "bangsa Indonesia belum merdeka sejak tahun 1945”. Mungkin bila guru meneruskan pertanyaannya dengan kata tanya mengapa kamu berpendapat bahwa bangsa Indonesia belum merdeka sejak tahun 1945? dianggap akan menghabiskan waktu dengan mendengarkan jawaban atau argumentasi siswa yang "ngalorngidul". Padahal, materi pelajaran masih cukup banyak untuk disampaikan kepada peserta didik untuk dihapal dan diingat. Dengan pertanyaan yang menggunakan kata tanya mengapa akan diperoleh jawaban argumentatif dari peserta didik. Bila hal itu dilakukan maka kemungkinan guru akan memperoleh pemahaman bahwa apa yang dideskripsikan peserta didik dengan jawaban tersebut bisa diterima atau dipahami. Jawaban argumentatif bisa menggambarkan kemampuan berpikir tingkat tinggi. Bahkan, akan muncul jawaban yang menggambarkan kemampuan berpikir kreatif sebagaimana 
ditawarkan dalam keterampilan abad ke-21. Ternyata, guru sejarah yang sudah mengikuti sosialisasi Kurikulum 2013 tersebut dan sudah tersertifikasi sebagai guru sejarah nampaknya belum berubah mind set-nya.

Nampaknya, rezim testing yang merupakan produk dari paradigma positivistik yang masih cukup kuat dalam pelaksanaan kurikulum sekolah di Indonesia juga sangat berpengaruh kuat pada narasi pedagogik guru di kelas. Baginya, mungkin, mengajar adalah menyampaikan materi pelajaran dan keberhasilan belajar harus diukur dengan menggunakan alat tes. Sekalipun Kurikulum 2013 sudah memberi ruang bagi terjadinya authentic assessment dengan menekankan pada penilaian proses, kinerja peserta didik atau produk yang bisa dihasilkannya, termasuk produk dari berpikir kreatif, dianggap akan menghabiskan waktu untuk mencapai kriteria kelulusan minimal (KKM).

\section{Berpikir Kreatif Imajinatif dalam Pembelajaran Sejarah}

Merasa penasaran dengan jawaban peserta didik bahwa "bangsa Indonesia belum merdeka sejak tahun 1945" penulis berusaha memperolah informasi dari yang bersangkutan. Penulis ingin mengetahui lebih lanjut mengapa dia mengatakan demikian. Atas izin dan bantuan guru pamong, Penulis berhasil menemuinya saat istirahat untuk mendengarkan pendapatnya. Pertemuan dengan dia dilakukan juga setelah jam sekolah selesai. Pertanyaan yang penulis anggap penting untuk memfasilitasi kemampuan peserta didik adalah dengan melakukan pertanyaan elaborative, misalnya dengan memintanya menjelaskan lebih lanjut mengapa dia berpendapat demikian. Penulis juga menggunakan kata tanya mengapa untuk menguji alasan atau argumentasinya. Penulis jelaskan juga bahwa Penulis senang diskusi dengannya dan akan mendengarkan alasannya memberikan pernyataan tersebut.

Melalui bincang-bincang dengannya, Penulis memperoleh kesan yang sangat baik bahwa anak ini cerdas. Dia ingin menyampaikan pendapat yang berbeda dibandingkan dengan teman-temannya yang pasti akan menjawab seragam: Indonesia sudah merdeka sejak Proklamasi Kemedekaan 17 Agutus 1945. Dia tahu bahwa itu merupakan tanggal penting yang selalu diperingati oleh bangsa Indonesia setiap tahun. Dan, setiap tahun pula bangsa ini seharusnya merefleksi arti kemerdekaannya dalam setiap upacara itu. Dia sudah tahu fakta sejarah itu sejak Sekolah Dasar. Tetapi di SMA, dia sudah merasa bosan kalau jawaban itu diulang-ulang kembali. Olah karena itu, katanya, dia ingin mengungkapkan jawaban lain yang berbeda tetapi dengan argumentasi. Sayang sekali kesempatannya untuk berargumentasi tidak difasilitasi oleh gurunya. Kemungkinan guru Sejarah menganggap argumenargumen itu merupakan penyimpangan dari narasi kurikulum yang guru fahami. Melalui obrolah dengan anak itu Penulis memperoleh jawaban yang sangat menarik:

"Saya tahu bahwa bangsa Indonesia sudah merdeka sejak Proklamasi Kemerdekaan 17 Agustus 1945. Bagi saya merdeka itu artinya bangsa ini terbebas dari segala bentuk penjajahan. Kita merdeka dari penjajah Belanda dan Jepang. Mereka adalah kekuatan yang sudah lama membuat bangsa ini kehilangan kedaulataannya, kehilangan identitas dirinya dan juga kehilangan kehormatannya. Sejak proklamasi kemerdekaan itu, bangsa ini memperoleh kedudukan terhormat sebagai bangsa yang berdaulat, mandiri dan bisa menentukan arah perjalanannya pada masa yang akan datang".

"Penjelasan kamu itu bertolak-belakang dengan jawaban kamu ketika gurumu bertanya tadi. Indonesia sudah mereka sejak 17 Agustus 1945. Mengapa bukan jawaban itu yang kamu sampaikan?” tanya penulis.

"Saya suka mengikuti berita TV. Berita yang sering saya ikuti adalah kampanye politik menjelang pemilihan presiden RI bulan April 2019. Saya mendengar penjelasan dari salah satu calon presiden bahwa bangsa Indonesia itu belum berdaulat dalam berbagai kehidupannya. Sebenarnya saya tidak terlalu mengerti mengapa seorang calon presiden mengatakan demikian. Yang saya tahu sejak RI merdeka berarti kita berdaulat. Penasaran dengan pernyataan itu saya terus mencari informasi dan mengikuti berita tentang kampanye politik. Dari banyak info yang saya dapat melalui berita TV, koran dan social media saya bisa menyatakan bahwa bangsa Indonesia memang belum merdeka. Itulah jawaban saya kepada guru sejarah saya".

"Buktinya apa?" Tanya Penulis.

"Bangsa Indonesia belum merdeka dari kemiskinan, kebodohan, keterbelakangan, kriminalitas, dan lain-lain. Bangsa yang sudah merdeka ini masih miskin. Sebagian bangsa Indonesia juga masih dibelenggu oleh pendidikan yang rendah. Kita masih ketinggalan dibanding negara tetangga. Saya kasihan dengan saudara-saudara yang tinggal di sekitar rumah saya. Sebagian mereka masih dihadapkan pada kesulitan hidup. Mereka tinggal di pinggir-pinggir kali dengan sanitasi yang buruk. Saya ingin memakmurkan mereka. Dalam kehidupan seharihari masih ditemukan kejahatan di sekitar kita. Jadi, dalam hal ini, saya merasa belum merdeka dari ancaman kriminalitas. Kata salah seorang calon presiden, kekayaan alam Indonesia masih dikuasai oleh bangsa penjajah. Bangsa Indonesia belum berdaulat dalam memenuhi kebutuhan pangannya. Kita masih impor pangan dalam jumlah besar. Itu yang saya dengar dari kampanye calon presiden. Bahkan saya juga merasa kaget dan cemas bahwa bangsa Indonesia akan bubar dalam beberapa tahun yang akan datang. Itulah yang menyebabkan saya menjawab bahwa bangsa Indonesia belum merdeka”.

Jawaban yang sangat cerdas dari siswa ini mendorong Penulis melanjutkan pertanyaan dengan menggunakan teknik "if history" atau teknik berandai-andai yang Penulis kutip dari Levstik and Barton (2005). Dengan Teknik ini Penulis berharap dia bisa berimajinasi untuk menjadi seseorang yang bisa melakukan sesuatu yang bisa membawa bangsanya mewujudkan kemerdekaannya dan membuat bangsanya merasa berdaulat. Imajinasi merupakan salah satu ciri berpikir kreatif yang Penulis kutip dari Piirto (2015) dan Trilling and Fadel (2011). Kedua penulis buku terebut menyatakan bahwa 
berpikir kreatif merupakan salah satu berpikir tingkat tinggi seperti halnya critical thinking. Berpikir seperti itu diperlukan oleh generasi millennial dalam mengarungi kehidupan di abad ke-21 ini.

Melalui 21st century skills generasi muda bisa mengisi peluang-peluang di era ini sekaligus memecahkan berbagai tantangan yang jauh lebih besar dibandingkan dengan abad sebelumnya. Guna menghadapi tantangan abad ke-21 peserta didik bisa dibekali berbagai keterampilan melalui pembelajaran sejarah (Wiriaatmadja, 2000). Melalui imajinasi, peserta didik bisa menjadi siapapun atau berbuat apapun (tentu yang baik) dalam ingatan, pikiran, bayangan atau harapannya. Imajinasi merupakan kekuatan berpikir yang yang menggambarkan kreatifitas. Dalam pelajaran sejarah, imajinasi didorong oleh guru melalui cerita sejarah, kisah masa lalu, narasi guru, atau ekspektasi guru. Imajinasi bisa berkembang dengan baik kalau guru bisa memfasilitasi peserta didik dengan materi sejarah yang imajinatif melalui proses pembelajaran yang merangsang mereka mengembangkan imajinasinya. Argumentasi peserta didik mengenai Indonesia belum merdeka merupakan novelty atau pernyataan baru yang merupakan bagian dari berpikir kreatif (Jackson, N. 2015)

Pertanyaan penulis lanjutkan: "jika kamu menjadi seorang presiden, apa yang akan kamu lakukan dan bagaimana cara membuat bangsa Indonesia merasa merdeka?" Kaget dengan pertanyaan Penulis, dia berpikir sebentar dan dengan dengan penuh percaya diri menjawab: "Saya ingin menjadi presiden T'Challa yang memerintah Negeri Wakanda seperti dalam film Black Phanter. Dalam film itu digambarkan bahwa pemimpin negara itu tidak hanya harus adil dan merakyat melainkan juga menjaga kekayaan alamnya untuk kepentingan warganya. Negeri Wakanda itu memiliki kekayaan yang tidak dimiliki negara lainnya, yaitu vibranium yang jatuh dari luar angkasa. Dengan Vibranium yang diolahnya maka Wakanda bisa mengembangkan teknologi yang lebih canggih dibandingkan negara lain dan bisa memakmurkan rakyatnya.

Presiden Wakanda sadar betul dengan potensi kekayaan alam ini dan oleh karena itu dia harus menjaga dan mengolahnya demi kemajuan seluruh rakyat. Banyak negara mengincar kekayaan alam Wakanda. Makanya, saya harus seperti presiden Wakanda, menjaga kekayaan alamnya dengan baik. Saya ingin memanfaatkan kekayaan alam Indonesia, mengolah dan memanfaatkannya untuk kemakmuran bangsa. Saya yakin dan optimis, Indonesia yang bisa mengolah potensi sumber daya alamnya tidak akan hancur atau punah sebagaimana disuarakan oleh salah seorang calon presiden. Sebagai Presiden, saya harus optimis membuat Indonesia lebih baik dan tetap berdaulat sebagaimana status negara yang sudah merdeka”.

Penulis sangat kagum dengan jawaban tersebut. Banyak hal yang disampaikannya dan tentu memerlukan tempat lebih banyak untuk dibahas di sini. Sangat disayangkan, pendapat kreatif-imajinatif itu tidak muncul di kelas karena tidak diwadahi dalam proses pembelajaran. Padahal, argumentasi tadi nampaknya memenuhi kriteria salah satu keterampilan abad ke 21 yaitu creativity yang sering dipadankan menjadi creativity and innovation skills (Trilling and Fadel, 2009).
Mereka mengatakan bahwa tujuan dari pengembangan keterampilan seperti itu adalah agar peserta didik mampu berpikir kreatif dengan cara mengemukakan beragam gagasan yang berbeda, menulis dengan argumentasi, melakukan elaborasi, menganalisis, dan mengevaluasi kembali gagasan yang sudah diungkap untuk ditingkatkan sebagai upaya kreatif. Orang kreatif biasanya bisa bekerjasama dengan baik dengan orang lain. Tentu saja bekerja secara kreatif pula. Dia bisa mengembangkan, menerapkan dan mengkomunikasikan gagasan baru dengan koleganya secara efektif, terbuka dengan pendapat siapa pun atau responsive dengan gagasan baru, mampu mendemonstrasikan keorisinilan gagasannya (Triling and Fadel, 2009: 59).

Berpikir kreatif itu bukan milik anak-anak yang memiliki kecerdasan yang tinggi. IQ bukan menjadi dasar bagi terbentuknya kreatifitas. Kreatifitas akan muncul kalau diberikan ruang untuk kreatif. Pertanyaan guru yang bersifat elaboratif seperti dengan menggunakan kata tanya mengapa dalam pertanyaan "mengapa kamu mengatakan bahwa Indonesia belum merdeka sejak tahun 1945” merupakan pertanyaan elaboratif untuk mendorong peserta didik berargumentasi. Jawaban argumentatif adalah jawaban kreatif. Menurut Trilling and Fadel (2009: 57):

creativity is based on something that virtually everyone is born with: imagination. People from widely diverse backgrounds and educational experiences have made creative, innovative contribution to all aspect of art, culture, science, and knowledge through the ages"

Yang paling menarik dari pendapat itu adalah aspek imagination. Ini merupakan kecerdasan yang sebenarnya secara tradisional atau konvensional dibangun melalui pembelajaran Sejarah. Melalui pembelajaran yang lebih fokus pada masa lalu, peserta didik diajak untuk berimajinasi ke dalam ruang atau tempat serta waktu dan tokoh sejarah. Dengan demikian, secara konseptual sebenarnya berpikir imajinatif adalah miliknya pelajaran sejarah, walaupun semua pelajaran bisa mengembangkan kemampuan berpikir seperti itu. Peserta didik yang bisa mengembangkan imajinasi tentang masa lalu adalah bukan hanya karena yang bersangkutan cerdas melainkan juga kreatif. Kecerdasan seperti itu tidak selalu dibangun melalui banyaknya materi pelajaran yang disampaikan.

Kreativitas bisa muncul bahkan dari materi yang tidak lengkap atau tidak utuh. Ketidaklengkapan dan ketidakutuhan bisa merangsang peserta didik untuk bertanya atau mencari jawaban sendiri. Pengetahuan yang sengaja dibangun oleh guru juga tidak selalu berpengaruh pada pembentukan kreativititas. Bahkan, kata Albert Einstein sebagaimana dikutif oleh Wikipedia (2019), imajinasi lebih penting daripada pengetahuan. Dalam buku klasik, Grammar of Science (2nd Edition), Pearson (1900) menyatakan bahwa knowledge is limited. Imagination encircles the world. The man without imagination may collect facts, but he cannot make great discovery. Dalam pandangan filosof Italia, Giambettista Vico (1668-1744), sebagaima dikutip oleh Sjamsuddin (2018), imaji atau fantasia bisa menggunakan kekuatan bahasa sehingga 
lebih hidup dibandingkan dengan temuan-temuan saintifik berbasis fakta.

Dalam pandangan Yilmaz (2007) imajinasi kesejarahan mengandung unsur empati. Peserta didik di atas berimajinasi untuk menjadi seorang Presiden Wakanda sekaligus berempati dengan nasib sebagian saudara-saudara yang tinggal di sekitar rumahnya. Dia seperti merasakan nasib orang lain. Oleh karena itu, dia ingin "memerdekakan" tetangganya dari kemiskinan, kebodohan dan kriminalitas. Jawaban ini jauh lebin tinggi tingkat berpikirnya dibandingkan dengan jawaban "Proklamasi Kemerdekan RI terjadi pada tanggal 17 Agustus 1945”. Kata Yilmaz (2007: 331) “empathy or historical imagination is the ability to see and judge the past in its own terms by trying to understand the mentality, frame of reference, belief, values, intention, and action of historical agents using a variety of historical evidence". Evidensi kesejarahan seperti peristiwa proklamasi dan evidensi sejarah kekinian yang dirasakan atau dialami oleh peserta didik menjadi frame of reference bagi mereka untuk berimajinasi soal negeri imajinatif Wakanda dan negeri yang kini ditempatinya: Indonesia.

Tidak ada data historis mengenai sebuah negara bernama Wakanda. Itu hanya ada dalam fiksi. Akan tetapi, fiksi telah menciptakan beragam imajinasi peserta didik termasuk imajinasi mengenai kemerdekaan dan kedaulatan. Pernyataan bahwa Indonesia belum merdeka dan keinginan salah seorang peserta didik menjadi seperti Presiden Wakanda menggambarkan anak yang berpikir kreatif-imajinatif. Dia berimajinasi untuk menjaga sumber daya alam seperti halnya Presiden Wakanda agar kekayaan alam Indonesia bisa digunakan sebesar-besarnya untuk membuat bangsa ini berdaulat dan makmur sebagai pengejawantahan dari cita-cita kemerdekaan. Imajinasi untuk berempati pada nasib sebagian warga yang miskin dan berempati ada mahluk hidup lainnya juga menggambarkan kecerdasan ekologis (Supriatna; 2016, 2018b). Berimajinasi bahwa penguasaan sebagian kekayaan alam Indonesia kini juga menggambarkan relasi kolonial yang juga ada benarnya di era kapitalisme global ini (Supriatna, 2018a). Berimajinasi untuk berempati pada masyarakat atau tokoh yang dipelajari juga meggambarkan empati kesejarahan (Endachott, 2014). Jawaban bahwa Indonesia sudah merdeka tahun 1945 adalah jawaban yang benar secara faktual tetapi hal itu bukan jawaban dari seorang peserta didik yang berpikir kreatif.

\section{Mendekonstruksi Pembelajaran Sejarah Untuk Memberi Ruang Kreatif}

Subjudul ini merupakan kiasan yang dikutif dari Munslow (2001), Deconstructing History. Mendekonstruksi bisa diartikan membongkar. Materi pelajaran sejarah yang hanya berisi sejumlah fakta harus "dibongkar" atau dilihat ulang dengan cara menambahkan materi-materi yang memberi peluang kepada peserta didik mengembangkan pikiranpikiran cerdasnya. Demikian juga gaya mengajar sejarah oleh guru yang mentransfer isi buku teks juga harus diperbaiki. Tentu saja, ruang kelas yang sudah permanen tempat peserta didik menerima materi pelajaran tidak bisa dibongkar. Hal yang saya tawarkan untuk dibongkar dalam mind set guru sejarah adalah gaya mengajar bussiness as usual.

Melalui dialog dengan guru pamong dan mahasiswa yang saya bimbing pada saat pelaksanaan PPL disepakati untuk menggunakan KD sebagaimana terdapat dalam Kurikulum 2013. Susunan materi pelajaran tidak harus berurutan sebagaimana tertulis dalam silabus. Silabus hanyalah sebuah dokumen yang bisa disesuaikan lagi sesuai dengan konteks dan urgensinya. Setiap materi yang dibahas harus bisa dihubungkan dengan persoalan kontemporer yang dihadapi peserta didik. Kami menyepakati pembelajaran yang kontekstual. Pertanyaan guru yang diuraikan di atas berbunyi “Apakah Indonesia sudah merdeka pada tahun 1945?” juga bukan pada KD mengenai "pemahaman mengenai Proklamasi Kemerdekaan” melainkan pada materi Pergerakan Nasional dan Sumpah Pemuda.

Pemilihan materi bisa fleksibel disesuaikan dengan kebutuhan termasuk isu kontekstual. Isu-isu kekinian mengenai pemilihan presiden, berkembangnya informasi tidak benar (hoaks) dalam dunia internet, masalah kebangsaan, munculnya masyarakat konsumen yang terkait dengan peserta didik menjadi topik terhubung. Saya teringat dengan Hyden White dalam bukunya Metahistory (1994) bahwa imajinasi kesejarahan tidak perlu dibatasi oleh disiplin akademik sejarah atau sejarah konvensional sebab imajinasi bisa merupakan sumber yang dapat kita gunakan untuk kepentingan masa kini dimana kita hidup. Kata White, we are free to conceive history as we please, just as we are free to make of it what we will. We come to history not for scientific truth but for aesthetic and ethical guidance" (pp.434). Tujuan dari "mendekonstruksi pembelajaran sejarah" adalah agar hambatan-hambatan yang sifatnya teknis instrumentalis atau karena mind set pengajar bisa dihilangkan. Dengan cara itu dibuka jalan atau ruang bagi proses pedagogik untuk mengembangkan kemampuan berpikir kreatif sebagaimana digagas dalam keterampilan abad ke 21. Dalam kegiatan dialog dengan guru dan mahasiswa PPL disepakati agar pembelajaran Sejarah diarahkan untuk mengembangkan kreatifitas-imajinatif melalui berbagai kegiatan pembelajaran.

Bila dalam pembelajaran Sejarah konvensional guru lebih banyak sebagai penyampai sejumlah fakta-fakta sejarah maka dalam kegiatan PPL berbagai metode disepakati untuk digunakan. Intinya adalah pembelajaran harus berpusat pada peserta didik dan guru hanyalah sebagai fasilitator. Dengan demikian, ruang untuk kreatif dibuka lebar agar peserta didik lebih banyak mengekspresikan pemikirannya yang tentu saja berangkat dari materi yang ada dalam kurikulum yang sudah dikembangkan.

Guru pamong mempersilahkan mahasiswa PPL untuk memilih beragam metode yang sesuai dengan materi pelajaran dan tujuan yang ingin dicapai. Metode "tradisional" dalam sejarah, yaitu ceramah, bercerita atau mendongeng tidak bisa diabaikan. Walaupun dalam metode tersebut guru nampak akan memerankan sebagai pusat kegiatan belajar, kegiatan belajar bisa diselingi dengan tanya jawab. Saat guru mengajukan pertanyaan dengan kata tanya mengapa, misalnya, maka pusat 
kegiatan belajar akan bergeser dari guru ke peserta didik. Yang lebih penting, melalui metode tersebut guru bisa mengajak peserta didik berargumentasi sekaligus berimajinasi ke masa atau kurun waktu yang diceriterakannya.

Guru juga bisa memfasilitasi peserta didik untuk berceritera kembali mengenai apa yang didengarnya. Metode berceritera juga sudah lama dilakukan oleh guru-guru Sejarah di Amerika Serikat. Hasil riset yang dilakukan oleh VanSledright dan Brophy (1992) menunjukkan bahwa story telling bisa merekonstruksi Sejarah peserta didik. Sejarah tidak hanya berisi kisah sebagaimana ditulis dalam buku teks atau kurikulum melainkan juga dialami. Peserta didik bisa bercerita mengenai apa yang dialami dan bermakna untuk orang lain. Saling berbagi cerita dari orang pertama yang punya pengalaman dari berbagai sumber akan memperkaya pembelajaran Sejarah. Ini seperti yang dikatakan Morris dalam "bringing history to life" atau membawa sejarah ke dalam kehidupan seseorang (Morris, 2009; Maulidah, 2017). Melalui rekonstruksi imajinatif itu kecerdasan peserta didik terbentuk dan Sejarah tidak hanya menjadi milik guru atau buku teks melainkan juga peserta didik.

Bermain peran juga merupakan metode yang disepakati dikembangkan oleh mahasiswa PPL. Melalui kegiatan ini diharapkan peserta didik bisa memerankan orang lain sambil berimajinasi mengenai tokoh yang diperankannya, ceritera atau kisah yang dimainkannya serta kurun waktu yang menggambarkan jiwa jaman tertentu. Mahasiswa disarankan untuk membaca ulang buku Piirto (2011) mengenai Creativity for the 21st Century Skills yang berisi langkah-langkah pembelajaran untuk membangun kreatifitas-imajinatif. Dalam buku itu dijelaskan bagaimana drama merupakan salah satu metode yang bisa memberi peluang peserta didik berkreasi mengenai penyusunan naskah, pemilihan kostum sesuai dengan karakter tokoh yang dimainkan, atau spontanitas berdasarkan imajinasi mereka. Tentu saja, sebelum peserta didik memainkan kisah atau karakter tertentu mereka harus dibekali terlebih dahulu dengan pemahaman yang baik mengenai kisah kejadian dari peristiwa tertentu.

Metode pembelajaran kooperatif juga bisa memfasilitasi peserta didik melakukan kegiatan yang akan menghasilkan kompetensi kreatifitas-imajinatif. Kami menyepakati peserta PPL memilih salah satu atau beberapa jenis pembelajaran ini. Yang penting, kegiatan kooperatif harus memberi peluang bagi terjadinya kerjasama, saling memberi dan menerima, menghargai pendapat, berargumentasi atau mengajukan gagasan-gagasan baru yang berbeda dengan gagasan orang lain. Jika ada pendapat peserta didik seperti di atas, yaitu "Indonesia belum merdeka pada tahun 1945" maka mereka harus segera difasilitasi oleh guru atau mahasiswa PPL dengan mengajukan pertanyaan dengan kata tanya mengapa. Jenis pertanyaan itu akan mendorong setiap yang ditanya untuk mencari argumentasi atau alasan sekaligus mencari rujukan. Keterampilan mencari rujukan bisa menggambarkan kreatifitas. Ini seperti cara kerja sejarawan dalam berinquiry sebagaima dikatakan Collingwood (Lemisko, 2004). Menurutnya, pertanyaan merupakan salah satu cara untuk mencari informasi mengenai peristiwa masa lalu. Keterbatasan fakta-fakta sejarah bisa dibantu dengan kemampuan sejarawan berimajinasi. Pertanyaaan guru sejarah dengan menggunakan kata tanya mengapa kepada peserta didik bisa mendorong mereka berkreasi dengan pikirannya, yaitu imajinasi.

Kata tanya mengapa hanyalah bagian dari sejumlah kata tanya yang bisa dikembangkan dalam kegiatan tanya jawab. Kegiatan tersebut bisa mendorong peserta didik tidak hanya berpikir kritis melainkan juga kreatif. Dari buku Fisher (2009) yang yang baca berpikir kritis-kreatif lebih menekankan pada aspek positif dan imajinatif. Ini cocok dikembangkan dalam pembelajaran. Penggunaan kata tanya yang mengambarkan ranah kognitif sebagaimana dikembangkan dalam Taksonomi Bloom juga bisa dipilih. Kata tanya seperti bagaimana, apa yang dapat Anda lakukan jika, atau kata kerja berbentuk penugasan seperti bisakah Anda deskripsikan, analisis, sintesakan lebih lanjut, atau bagaimana dengan penilaian Anda mengenai hal itu, dan lain-lain juga disepakati untuk digunakan. Kami setuju untuk melakukan kegiatan tanya jawab lebih sering dalam semua tatap muka sehingga kompetensi berpikir kreatif imajinatif bisa terbentuk.

Melalui kegiatan tanya jawab diharapkan peserta didik dapat melakukan konektivitas dan sistesis dari apa yang dipelajari mengenai materi sejarah masa lalu dengan situasi masa kini. Konektivitas itu seperti peristiwa sejarah, satu peristiwa tidak berdiri sendiri dan selalu terhubung dengan peristiwa lain. Konektivitas juga seperti dalam hubungan sebab akibat, peristiwa masa lalu berpengaruh pada masa kini. (Harris, 2014). Misalnya, pada kajian mengenai Sumpah Pemuda, guru tidak hanya dapat mengajukan pertanyaan apa, di mana, siapa dan kapan peristiwa itu dilaksanakan. Guru dapat melengkapi dengan pertanyaan seperti "berangkat dari pemahaman kalian mengenai Sumpah Pemuda, apa yang dapat kalian atau para pemuda lakukan sekarang untuk menjaga persatuan bangsa? Apa yang dapat kalian perankan untuk mencegah berita hoaks yang mengancam persaudaraan sebangsa? Bagaimana cara kalian mencintai Bahasa Indonesia dalam kehidupan sehari-hari? Pertanyaan sejenis bisa dilakukan sesuai dengan isi materi pelajaran dan konteks dunia nyata peserta didik.

Kegiatan tanya jawab tidak hanya menghasilkan jawaban atau pemikiran kreatif. Kegiatan tersebut juga bisa mendekatkan hubungan antara guru dan peserta didik. Posisi guru sebagai pusat kegiatan belajar akan menjauhkan dirinya dengan peserta didik. Kegiatan tanya jawab yang disertai dengan reward, penghargaaan atau penguatan atau tanpa mencela jawaban peserta didik bisa merupakan sarana memotivasi. Reward juga bisa mendekatkan hubungan emosional antara guru dan siswa. Pembelajaran akan terasa lebih nyaman apabila hubungan semua pihak terjaga dengan baik. Kata Rosiek dan Begheto (2009) relasi yang baik antara guru dan siswa dalam proses belajar mengajar, termasuk dalam kegiatan tanya jawab, akan menghasilkan atau memperkuat unsur emosi dan imajinasi. Dalam proses pembelajaran yang menekankan pada aspek transferring of knowledge, kedua aspek itu sulit untuk dihasilkan.

Terbentuknya suasana nyaman dalam proses belajar bisa menjadi kondisi yang akan mempengaruhi peserta didik

HISTORIA: Jurnal Pendidik dan Peneliti Sejarah, p-issn:2620-4789 | e-issn:2615-7993 
berkreasi. Kedekatan guru dengan siswa yang ditandai dengan penempatan posisi sebagai sahabat di kelas, pendengar yang baik, pemberi pujian, tidak hanya menjadi sarana untuk memotivasi belajar. Kedekatan tersebut juga menjadi ruang untuk berpikir, berbicara dan bekerja secara kreatif dan bebas di dalam kelas tanpa ada belenggu psikologis guru sebagai "pengendali" kelas. Dalam pandangan Pacifici and Garrison (2004: 119-132), guru sebagai fasilitator harus bisa menciptakan teachable moment, yaitu sebuah kondisi dimana guru dan peserta didik merasa memiliki kedekatan dalam interaksi di kelas. Kedua pihak harus berada dalam ikatan emosi, intuisi, dan imajinasi bahwa mereka adalah sama-sama sedang belajar (learning). Teachable moment terjadi ketika guru dan siswa saling berbagi secara ikhlas (genuine), saling memahami, menaruh perhatian pada hal yang sama tanpa harus selalu bekerja sesuai dengan kepentingan dokumen kurikulum. Dalam hal ini, kurikulum adalah adalah praksis (Doll, 1995) yang berisi relasi di antara keduanya untuk sama-sama mecapai tujuan. Bila tujuannya adalah untuk membangun kemampuan berpikir kreatif-imajinatif maka itulah kurikulum yang mereka kembangkan.

\section{Berpikir Kreatif-imajinatif Peserta Didik}

Berpikir kreatif-imajinatif sebagai tujuan pembelajaran yang disepakati dalam kegiatan PPL mahasiswa Pendidikan Sejarah UPI ini berusaha kami capai melalui proses pembelajaran. Mahasiswa melaksanakan kesepakatan tersebut dengan kegiatan-kegiatan seperti: 1) menyusun kembali rencana program pembelajaran (RPP) yang baru dan berbeda dengan RPP yang disusun sebelum mereka tampil 2) memasukkan indikator-indikator pencapaian berpikir kritis kreatif dan imajinatif ke dalam RPP. Indikator-indikator tersebut disandingkan dengan indikator yang mengacu pada rumusan Kompetensi Dasar yang ada dalam Kurikulum. Dalam hal ini, indikator sebenarnya lebih banyak mengacu pada semangat untuk mencapai Kompetensi Inti Kedua: kreatifitas. 3) Mempelajari isi buku teks yang digunakan dan diperkaya dengan bacaan lain termasuk dari sumber online yang relatif lebih mudah diperoleh.

Dalam hal ini, kami menyarankan agar mereka juga mempelajari isu-isu kontemporer dan kontekestual yang kini diketahui, dihadapi dan dirasakan peserta didik. Ini penting agar proses pembelajaran Sejarah selanjutnya tidak hanya bisa kontekstual tetapi juga bermakna bagi peserta didik. Kami juga menyarankan agar setiap materi pelajaran Sejarah selalu menghubungkan dengan kondisi zaman yang dihadapi peserta didik. 4) Mengembangkan kegiatan pembelajaran dengan metode-metode yang disepakati bersama. Kegiatan tanya jawab yang diikuti dengan reward bagi setiap penanya, pembelajaran kooperatif, simulasi seperti drama dan bermain peran, penugasan untuk ber-inquiry dari sumber-sumber lain juga dilaksanakan. 5). Tidak kalah pentingnya adalah penilaian proses dan otentik yang mendapat porsi lebih besar dibandingkan dengan penilaian dengan menggunakan alat test. Dengan demikian, penilaian bersifat kualitatif dengan menggunakan lembar observai,i catatan guru, rubrik, dan portofolio.
Sebagai dosen pembimbing PPL di SMA berklaster satu tersebut bersama dengan guru pamong juga dilibatkan dalam proses pembelajaran. Kami diposisikan untuk melakukan penilaian. Penilaian tidak hanya dilakukan terhadap penampilan mahasiswa PPl melainkan juga terhadap keseluruhan proses pembelajaran. Kami juga ikut mengamati respons peserta didik dalam melakukan kegiatan tersebut. Indikator-indikator berpikir kreatif-imajinatif juga kami gunakan untuk menjadi alat penilaian. Tidak seperti guru pamong, saya terlibat dalam beberapa kegiatan tatap muka dan saya bisa meyakinkan bahwa berpikir kreatif-imajinatif sebagai sebuah tujuan bisa dicapai melalui pembelajaran tersebut.

Berdasarkan pengamatan dan penilaian kami terhadap proses pembelajaran dan penampilan peserta didik, unsurunsur kreatif-imajinatif nampak terbentuk melalui proses pembelajaran. Wawancara saya dengan beberapa peserta didik setelah kegiaan belajar mengajar berakhir diperoleh informasi bahwa mereka senang belajar dengan mahasiswa PPL. Ketika penulis bertanya dengan menggunakan kata tanya mengapa, mereka menjawab bahwa mahasiswa PPL sangat bersahabat, seperti teman, suka berceritera, memberikan contoh-contoh dengan tayangan gambar dan video yang menarik, lebih sering memberi kesempatan bertanya dan menjawab pertanyaan. Mereka juga menyatakan bahwa guru muda mereka tidak pernah menyalahkan dan bahkan semua jawaban selalu dikatakan bagus. Kegiatan diskusi kelas, sosiodrama, nonton film juga sangat menginspirasi dan memfasilitasi mereka mengembangkan imajinasinya.

Jawaban mereka mengingatkan saya pada unsur-unsur kreatifitas yang dikembangkan oleh Piirto (2011: 43) yaitu inspiration, imagery, imagination, intuition, insight, incubation dan improvisation. Ketujuh unsur itu bisa menggambarkan cara guru mengajar yang kreatif, bisa juga menggambarkan kemampuan berpikir kreatif peserta didik. Guru kreatif bisa menginspirasi peserta didik dengan cara memotivasi untuk mengkreasi sesuatu seperti cerita atau tulisan. Dia bisa memilih metode, materi pelajaran atau mengolah pelajaran yang menginspirasi. Penambahan materi dengan novel atau autobiografi, misalnya, ke dalam pembelajaran sejarah bisa menginspirasi. Dari hasil observasi, salah seorang mahasiswa PPL kami juga menggunakan novel dari karya Pamoedya Ananta Toer berjudul Bumi Manusia. Novel itu menginspirasi peserta didik bagaimana masyarakat pada zaman pergerakan nasional melakukan perlawanan terhadap penjajah dengan cara berbeda. Guru juga memotivasi peserta didik untuk berlatih menulis pengalaman pribadi yang menarik yang dimaknai sebagai peristiwa bersejarah bagi dirinya.

Apek lain dari unsur kreatif adalah imagery. Menurut Piirto (2011) imagery is psychological, the ability to mentally represent imagined or previously perceived objects accurately and vividly. Imagery is attribute to imagination. Imagery is not only visual, but also auditory, tactile, olfactory, and gustatory". Melalui penggunaan bacaan seperti novel, pertanyaan dengan teknik "if history" peserta didik berfantasi, mencitrakan diri seperti tokoh yang diidamkannya dalam sejarah, atau bermetafora menjadi seseorang yang disukainya. Berdasarkan 
pengamatan saya, peserta didik menyukai cara belajar sejarah dengan menggunakan media dan metode belajar seperti itu, termasuk dalam kegiatan tanya jawab. Jawaban peserta didik dengan teknik bertanya "if history": "jika kamu menjadi presiden apa yang akan kamu lakukan?", dan kemudian dijawab "ingin seperti tokoh tertentu yang dilihat dalam film atau baca melalui novel” merupakan jawaban imagery dan metafora. Beberapa jenis pertanyaan imagery juga dilakukan oleh mahasiswa PPL dan menghasilkan jawaban yang menggambarkan berpikir kreatif-imajinatif. Pertanyaan kreatif telah melahirkan jawaban yang kreatif dan peserta didik nampak menikmati learnable moment melalui cara belajar sejarah seperti itu.

Dua pendapat dari sekian banyak pendapat kreatifimajinatif peserta didik dalam menghubungkan materi Sejarah masa lalu dengan masa di mana mereka berada dicantumkan di bawah ini:

"Kita sudah belajar tentang materi strategi perlawanan bangsa Indonesia terhadap penjajahan bangsa asing. Jika dulu bangsa Indonesia melawan penjajah secara fisik, melalui perang, sekarang kita pun menghadapi permasalahan yang hampir sama mengancamnya. Dulu para pejuang berjuang melalui perlawanan senjata, berkorban jiwa dan harta. Sekarang kita melawan penjajahan yang efeknya besar juga. Di masa modern ini, bangsa Indonesia masih mengalami penjajahan secara ekonomi. Penjajahan ekonomi berkaitan dengan perang ekonomi (trade war) antara negara besar seperti Amerika Serikat dengan China. Sebagai negara yang tidak terlalu besar perann ya di dunia internasional, Indonesia turut merasakandampakyangbesardariperangdagangtersebut. Indonesia menjadi sasaran empuk para kapitalis dalam menjual barang dagangannya di Indonesia. Akibatnya, Indonesia hanya menjadi bangsa konsumtif dan tidak memiliki kemandirian dalam mengembangkan produk lokal yang tentunya baik untuk kelangsungan bangsa Indonesia. Hal yang bisa kita lakukan sebagai pemuda generasi bangsa, meskipun hanya memiliki impact kecil dalam perekonomian Indonesia, adalah tetap berjuang agar Indonesia merdeka secara ekonomi. Kesadaran bangsa Indonesia dalam menggunakan produk-produk dalam negeri masih sangat rendah. Jika dibandingkan dengan sesama negara lain seperti Thailand, Indonesia masih jauh di bawah negara tersebut soal kepercayaan terhadap produk dalam negeri. Bangsa Indonesia masih belum secara optimal dalam menggunakan produk dalam negeri yang kualitasnya tidak jauh dengan barangbarang impor. Bangsa Indonesia masih saja tertarik dengan barang impor yang dinilai lebih "wah" atau "keren". Sebagai generasi penerus, tentunya berharap bangsa Indonesia lebih banyak menggunakan produk dalam negeri. Selain meningkatkan kemandirian dalam bidang ekonomi, semangat para pelaku usaha dalam negeri akan turut menaikkan perekonomian Indonesia. Artinya kesejahteraan bersama, bisa terwujud".
"Selain penjajahan ekonomi, bangsa Indonesia mengalami penjajahan ideologi (pemikiran). Ideologi ada karena manusia berpikir. Ideologi tidak dapat dimusnahkan. Banyak anak muda Indonesia sekarang yang mengamalkan ideologi kebebasan, liberalisme, sosialisme, dsb. Secara pribadi, bukan berniat menjelekkan ideologi atau bagaimana, tetapi sekeras apapun kita memerangi ideologi secara offensive, seharusnya tidak seperti itu. Ideologi itu intinya seperti agama ada plus minusnya. Kita harus tahu mana yang harus kita ambil dan mana yang harus kita tolak. Karena ideologi itu tidak muncul secara tiba-tiba, karena hal itu adalah reaksi dan pemikiran manusia terhadap suatu permasalahan. Kita hanya harus mengetahui impact ideologi yang diterapkan. Terkadang ideologi dari luar itu tidak sesuai dengan kepribadian bangsa Indonesia yaitu Pancasila. Kita sebagai generasi penerus harus dapat menyaring segala pengaruh yang datangnya dari luar. Bukan anti, tetapi kritis terhadap segala bentuk penyebaran paham atau ideologi lain. Dalam dunia pendidikan, kita diajarkan oleh guru-guru sejarah kita ....soal ideologi itu. Ya, pada intinya kita harus tahu dan dapat mengambil baiknya serta membuang yang jeleknya dari ideologi-ideologi tersebut. Pancasila harus menjadi ideologi utama yang dianut bangsa Indonesia sampai kapanpun".

Dua perdapat peserta didik di atas tidak hanya menggambarkan kemampuan berpikir tingkat tinggi. Pendapat di atas juga menggambarkan kemampuan berkreasi dalam bentuk pemikiran mengenai apa yang mereka lakukan. Belajar dari sejarah adalah untuk masa kini. Dua pendapat di atas merupakan pendapat kreatif tentang materi Sejarah yang dihubungkan dengan persoalan kontekstual yang kini mereka hadapi. Keduanya juga menggambarkan kemampuan imajinatif menjadi pelaku sejarahnya. Mereka ingin memerankan diri sebagai pejuang agar ekonomi Indonesia maju dan berdaulat. Mereka juga ingin agar ideologi Pancasila dilestarikan agar bangsa ini tidak ditelan oleh pengaruh buruk faham dari luar.

Memberikan peluang sebanyak mungkin kepada peserta didik untuk berdiskusi, melakukan pembelajaran kooperatif, sosiodrama, melaksanakan tugas ke museum, mengumpulkan informasi dari beragam sumber-sumber khususnya online merupakan pembelajaran yang konstruktif. Peserta didik difasilitasi mengonstruksi pemahaman, kesadaran dan keterampilan berpikir kreatif-imajinatif. Tanpa merujuk pada aspek teoretis pembelajaran kontruktivistik, mahasiswa PPL memfasilitasi peserta didik menjadikan materi sejarah sebagai sejarah miliknya sendiri. Mereka difasilitasi untuk mengambil inspirasi, mengembangkan imaji atau citra dari cerita guru, bacaan novel dan lain-lain tanpa harus terlalu banyak disajikan dengan sejumlah fakta-fakta sejarah yang biasanya membosankan.

Imajinasi peserta didik berkembang dengan baik seperti nampak pada karangan singkat mengenai tokoh tertentu atau komentar mereka mengenai kejadian kontemporer. Ini 
dibangun dari materi Sejarah yang dipelajarinya. Naskah drama yang mereka buat juga tidak hanya menggambarkan naskah berbeda dari aslinya melainkan telah dikembangkan menjadi naskah yang "kekinian" sesuai konteks zaman mereka. Melalui kegiatan tersebut, nampak unsur imagination, sebagai salah satu unsur kreativitas yang terbentuk, walaupun perlu penilaian lebih komprehensif mengenai karya-karya mereka. Tentu pendapat filosof Yunani, Aristoteles, yang menyatakan bahwa karya kreatif-imajinatif seperti drama, puisi, dan fiksi adalah lebih nyata atau lebih hidup dari sejarah yang berisi kumpulan fakta, layak didiskusikan. Akan tetapi dua pendapat berikut di bawah ini bukan fiksi atau drama melainkan imajinasi diri mereka sebagai pemuda yang harus melakukan peran historisnya pada masa kini:

“Berkaitan dengan materi Sumpah Pemuda, sangat sesuai dengan kita sebagai pemuda masa kini. Pemuda masa kini yang dikenal dengan generasi millennial dihadapkan pada banyak masalah, salah satunya adalah hoaks yang sering menjerumuskan pada isu SARA. Terkait hoaks, banyak sekali zaman sekarang peredaran informasi dari berbagai media seperti Internet yang mengabarkan berita tidak benar atau hoaks. Apalagi sekarang yang sering disulut itu soal SARA. Mungkin benar, penting sekali mempelajari Sejarah itu untuk menghadapi dan menjawab tantangan zaman. Kalau kita berkaca pada masa lalu, para pemuda dulu juga menghadapi berbagai keragaman yang ada, sama sekarang juga. Tidak melihat suku bangsa, agama, budaya, dsb kita dipersatukan dengan namanya Indonesia. Mungkin cara yang dapat dilakukan pemuda saat ini adalah tidak provokatif, menjaga hubungan yang harmonis dengan sesama bangsa Indonesia, yang terpenting jangan suka nyebar berita hoaks yang dapat memicu terjadinya kemarahan".

"Cara kita untuk mengambil nilai atau makna dari peran pemuda zaman dulu dalam menghadapi keragaman adalah bangun komunikasi yang baik antar anak bangsa misal dalam forum silaturahmi. Sehingga, hal itu akan terbina hubungan yang erat antar sesama pemuda. Nah disitu tuh kita bisa saling sharing masalah yang dihadapi pemuda, khususnya untuk bagaimana ke depannya Indonesia. Penting juga untuk dibahas, kalau berbicara soal hoaks yang menjurus ke SARA, selain menjaga hubungan baik antar bangsa Indonesia adalah dengan cara memeriksa kebenaran setiap informasi yang kita dapatkan. Di sejarah diajarkan namanya kritik sumber, ya dapat diterapkan juga dalam kehidupan sehari-hari. Kalau misalkan kita selektif dalam mencerna terus menjaring informasi, yakin tidak akan terjadi kegaduhan".

Keteramplan berpikir kreatif-imajinatif terbentuk melalui kegiatan pembelajaran sejarah di atas. Peserta didik ditempatkan dalam posisi pembelajar Sejarah yang aktif mengembangkan pikiran-pikiran cerdas dari materi sejarah yang dipelajarinya. Mereka juga memiliki ide-ide kreatif untuk mengaplikasikan materi yang dipelajarinya ke dalam kehidupan sehari-hari. Hal ini seperti yang dikatakan oleh Levstik dan Barton bahwa mempelajari sejarah tidak hanya untuk bernostalgia pada masa lalu tetapi juga untuk memahami masa kini dan merancang kehidupan yang lebih baik pada masa yang akan datang. Istilahnya adalah history helps us fictures possible future (Levstik and Barton, 2005: 3). Melalui pembelajaran seperti di atas, peserta didik tidak hanya mempelajari konsep merdeka sebagaimana pendekatan konvensional pembelajaran sejarah, yaitu merdeka dari penjajah Belanda atau Jepang pada akhir Perang Dunia Kedua. Di bawah fasilitasi peserta PPL, mereka juga berimajinasi secara kreatif lewat lisan dan tulisan bahwa konsep merdeka digunakan untuk melihat relasi antara fakta objektif merdeka berupa Proklamasi Kemerdekaan dengan realitas imajiner.

Realitas imajiner itu berangkat dari fakta-fakta historis yang mereka alami bahwa mereka merasakan dalam kehidupan sehari masih banyak penjajahan. Mereka merasa dijajah oleh kemiskinan, kriminalitas, kebodohan, dan lainlain yang disebabkan oleh lambatnya bangsa ini membangun dirinya dalam mengisi kemerdekaan. Bagi mereka kini, penjajahan tidak lagi hadirnya tentara Jepang atau pasukan Belanda. Penjajahan ada dalam kehidupan sehari-hari. Kemiskinan materi menyebabkan kriminatas yang akan merasmpas kehidupan sosial yang nyaman pada masyarakat merdeka. Kebodohan akan mengancam kohesi sosial atau integrasi bangsa. Masyarakat yang bodoh akan mudah "diadu-domba", tidak kritis menerima berita hoaks yang pada akhirnya akan mengganggu hubungan harmonis sesama anak bangsa. Pendapat-perdapat tersebut muncul dari peserta didik melalui pembelajaran Sejarah yang merangsang mereka mengembangkan kemampuan berpikir kreatif imajinatif.

Penulis tetap meyakini bahwa peserta didik sudah tahu bahwa bangsa Indonesia sudah memproklamasikan kemerdekaannya pada tanggal 17 Agustus 1945. Akan tetapi, mereka menyadari bahwa penjahahan tidak berakhir sampai sebuah bangsa memproklamasikan kemerdekaannya. Penjajahan terus berlangsung dalam beberapa bentuk yang tidak kasat mata. Apabila ada pernyataan seperti itu kita bisa mengajukan pertanyaan dengan kata tanya mengapa dan bagaimana serta pendekatan pembelajaran yang membuat peserta didik mengembangkan pikiran kreatif-imajinatif.

\section{SIMPULAN}

Kemampuan berpikir kreatif-imajinatif peserta didik akan terbentuk apabila proses pembelajaran memberi ruang untuk itu. Sebaliknya kemampuan tersebut tidak akan terbentuk apabila pembelajaran sejarah lebih banyak berisi pemaparan fakta-fakta, fokus pada masa lalu dan berakhir pada kurun waktu zaman tertentu dan tidak dihubungkan dengan persoalan kekinian. Di era teknologi informasi dan komunikasi dimana sumber pembelajaran sejarah sangat berlimpah guru dan peserta didik memiliki peluang untuk mengajar dan belajar sejarah dengan kreatif. Guru bisa menggunakan metode tradisional melalui cerita sambil mengajak peserta didik berimajinasi ke zaman yang dipelajarinya. Guru dapat memfasilitasi peserta didik "berwisata" ke masa lalu untuk bermetafora dan melalukan tindakan-tindakan historis. Dari hasil "wisata" itu, mereka bisa ditugasi untuk memerankan dirinya sebagai pelaku sejarah pada zamannya. Pemanfaatan 


\section{Nana Supriatna \\ Pengembangan Kreativitas Imajinatif Abad Ke-21 dalam Pembelajaran Sejarah}

teknologi komunikasi dan informasi yang tersedia di era ini akan sangat membantu. Pemutaran film sebagai media pembelajaran atau pemanfaatan alat perekam yang tersedia dalam gawai peserta didik bisa menghasilkan gagasan kreatifimajinatif sekaligus produk atau hasil dari pembelajaran. Untuk mencapai hal itu, pola pikir (mind set) guru sebagai hanya penyampai fakta-fakta sejarah harus diubah. Guru sejarah bukan sebagai pihak yang harus mentransfer isi dokumen kurikulum melainkan sebagai pengembang kurikulum sekaligus fasilitator dalam berdialog dengan peserta didiknya. Hubungan dialogis kedua belah pihak akan menjadi sarana terbentuknya teachable and learnable moment untuk memroses dan menghasilkan gagasan-gagasan kreatifmajinatif.

\section{REFERENSI}

Doll, W.E, Jr. (1995). A Post-Modern Perspective on Curriculum, New York: Teachers College, Columbia University.

Endachott, J.L. (2014). Negotiating the Process of Historical Empathy, dalam Theory and Reseach in Social Education, 42: 4-34, 2014.

Griffin. (2012). Assessment and Teaching for the 21st Century Skills. New York: Springer.

Hart, A.B. (1910). Imagination in History, dalam The American Historical Review, Vol 15 No 2 (January 1910) pp 227251), tersedia dalam http://www.jstor.org/stable/1838332

Harris, L.M. (2014). Making Connection for Themselves and Their Students: Examining Teachers Organization of World History', dalam Theory and Reseach in Social Education, 42: 336-374,2014.

Hasan, S.H. (2004). Kurikulum dan Tujuan Pendidikan Nasional, makalah stadium generale, Bandung: PPS UPI.

Jackson, N. (2015). Creativity in History Teaching and Learning, in Subject Centre for History, Classics and Archeology, tersedia dalam Norman.jackson@heacademy.ac.uk.

Lemisko, L.S. (2004). 'The Historical Imagination: Collingwood in the Classroom', dalam Canadian Social Studies. Vol 38. Number 2, Winter 2014.

Levstik, L.S and Barton, K (2015). Doing History: Investigating with Children in Elementary and Middle Schools. New York: Routledge.

Maulidah, N (2017). A Critical Review about Bringing History to Student's Life by Shaping 21st Century Learning Environment to Improve Student's Social Skills in Indonesia Elementary Social Studies, Proceeding of Adved 2017- 3rd International Conference on Advances in Education and Social Sciences, 9-11 October 2017 Istambul, Turkey.

Morris, R.V. (2009). Bringing History to Life: First Person Historical Presentation in Elementary and Middle Classrooms. New York: Rowman and Littlefield Education.

Munslow, A. (2001). Deconstructing History. London: Routledge.
Pacifici, L and Garrison J. (2004). Imagination, Emotion and Inquiry: The Teachable Moment, dalam Contemporary Pragmatism, Vol. 1 No. 1 (June 2004) 119-132.

Partnership for 21st Century Skills, tersedia dalam www.21stcenturyskills.org

Pearson, K. (1900). Science of Imagination, Grammar of Science (2nd Edition). London: Adam \& Charles. Link tersedia di: http://www.ebooksread.com/aothors-eng/karl-pearson/ the-grammar-of-science-hci.shtml

Piirto, J. (2011). Creativity for the 21st Century Skills. Rotherdam: Sense Publishers.

Rosiek, J dan Begheto, R.A. (2009). Emotional Scaffolding: the Emotional and Imaginative Dimentions of Teaching and Learning, book chapter 9, BookId 1649ᄀ_ChapID 9_Proof\#-25/05?2009.

Sjamsuddin, H. (2018). Ironi dan Tragedi Masyarakat Konsumen Era Postmodernisme, Kata Pengantar untuk buku Prosa dari Praha (Nana Supriatna, 2018), Bandung: Rosda.

Supriatna, N. (2016). Ecopedagogy, Mengembangkan Kecerdasan Ekologis dalam Pembelajaran IPS. Bandung: Rosda

Supriatna, N. (2007). Konstruksi Pembelajaran Sejarah Kritis. Bandung: Historia Utama Press

Supriatna, N. (2018a). Prosa dari Praha, Narasi Historis Masyarakat Konsumen era Kapitalisme Global. Bandung: Rosda.

Supriatna, N. (2008b). Ecopedagogy in History Learning. Bandung: Buku Langka Indonesia.

Trilling, B and Fadel C. (2009). 21st Century Skills, Learning for Life in Our Time. San Francisco: Josey-Bass.

Van Sledright, B dan Brophy, J. (1992). Storytelling, Imagination, and Fanciful Elaboration in Children's Historical Reconstruction, in American Educational Research Journal, Winter 1992, Vol 29 No 4 pp 837-859.

White, H. (1994). Metahistory, The Historical Imagination in the Nineteenth Century Europe. New York: Prentice Hall.

Wikipedia. 'Imagination', http://en.em.wikipedia.org

Wiriaatmaja, R. (2000). Sejarah dan Pendidikan Sejarah dalam Menghadapi Tantangan abad ke-21. Historia, Jurnal Pendidikan Sejarah, No 1 Vol 1/2000.

Yilmaz, K. (2007). Historical Empathy and Its Implication for Classroom Practices in Schools, dalam The History Teacher, Vol 40, No 3 (may 2007), pp 331-337, tersedia di http://www.jstor.org/stable/30036827 